\title{
Use and Management of Animal Manure by the Communal Farmers, Seke District, Mashonaland East Province, Zimbabwe
}

\section{Parwada $C^{1,2^{*}}$ Chigiya $V^{1,3}$ Ngezimana $W^{1}$ Chipomho $J^{1} \quad$ Bandason $W^{2}$ Nyamushamba \\ G.B ${ }^{2}$}

1.Marondera University of Agricultural Sciences and Technology, Department of Horticulture, P. O. Box 35 Marondera, Zimbabwe.

2.Faculty of Agricultural Sciences, Department of Horticulture, Women's University in Africa, P.O. Box 1175, Marondera, Zimbabwe

3.Seke Teachers College, Mangwende Road, 16120, Chitungwiza P.O. Box Sk 41, Seke, Zimbabwe

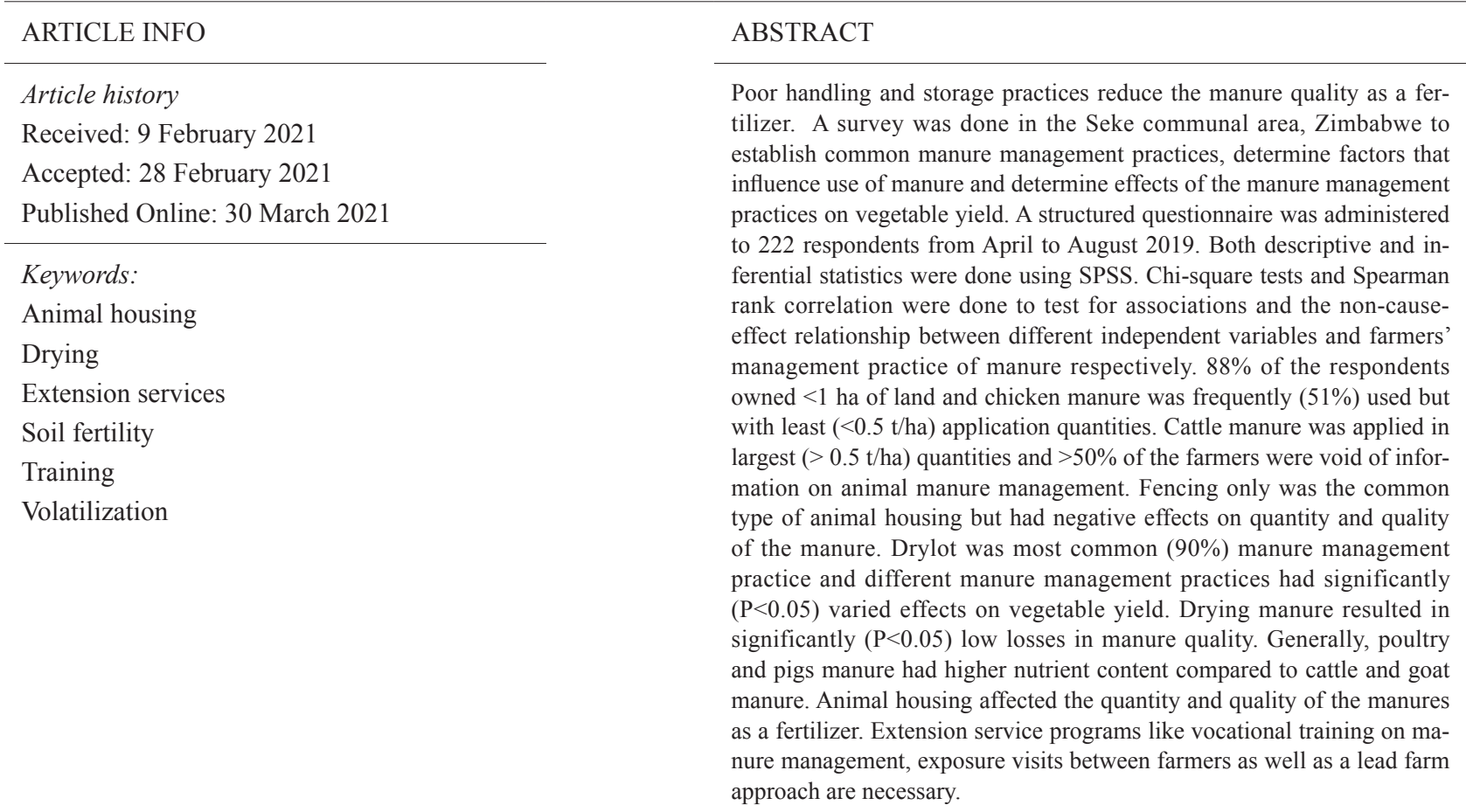

\section{Introduction}

The sub-Saharan African (SSA) has the highest prevalence of undernourishment and the highest rise in pro- portion of people who are food insecure caused by poor soil fertility, particularly low soil nitrogen (N) (Wuta and Nyamugafata, 2012). Fertilizer consumption in most SSA countries is estimated to $<6 \mathrm{~kg} \mathrm{ha}^{-1}$ e.g in Mozambique

*Corresponding Author:

Parwada $C$,

Marondera University of Agricultural Sciences and Technology, Department of Horticulture, P. O. Box 35 Marondera, Zimbabwe; Faculty of Agricultural Sciences, Department of Horticulture, Women's University in Africa, P.O. Box 1175, Marondera, Zimbabwe; E-mail: cparwada@gmail.com 
and Zimbabwe which is far below the recommended rates by $10-50 \%$ (Rusinamhodzi et al., 2013) compared to countries such as Malawi $\left(40 \mathrm{~kg} \mathrm{ha}^{-1}\right)$ and South Africa $\left(62 \mathrm{~kg} \mathrm{ha}^{-1}\right)$. The general use of fertilizer in countries like Zimbabwe is below average the level in SSA estimated at $14.7 \mathrm{~kg} \mathrm{ha}^{-1}$. It further falls way below the Abuja declaration on fertilizer use for an African green revolution that emphasizes the increase of fertilizer use in SSA from 8 to $50 \mathrm{~kg} \mathrm{ha}^{-1}$ by 2015 (Bindraban et al., 2018). Most communal farmers in the SSA region do not afford to buy commercial fertilizers thereby use low (on average $\leq 8 \mathrm{~kg}$ $\mathrm{N} \mathrm{ha}^{-1} \mathrm{yr}^{-1}$ ) fertilizer application rates (AGRA, 2013). The low fertilizer application rates resulted in a higher nitrogen $(\mathrm{N})$ uptake by crops than the $\mathrm{N}$ input from fertilizer (Jakhro et al., 2017). This mining of nutrients contributes to soil depletion which then limits agricultural sustainability. Alternatively, farmers can use cheap on-farm sources of fertilizers e.g the animal manure.

Animal manure has been used as a fertilizer since the ancient times and if well-managed it can promote sustainable agriculture and increase crop production, especially in the resource constrained smallholder farmers (AGRA, 2013). The manure contains important plant nutrients such as $\mathrm{N}$, phosphorus $(\mathrm{P})$, potassium $(\mathrm{K})$, and other secondary nutrients and trace elements, with farmers all over the world having discovered its benefits and associated it with increased crop production (Efthimiadou et al., 2012). The animal manure, unlike synthetic fertilizers, also provides organic matter that can enhance soil infiltration rates, improve water holding capacity, increase cation-exchange capacity (CEC) (Parwada and Van Tol, 2018), and increase soil C (Wuta and Nyamugafata, 2012). Nevertheless, most communal farmers in the SSA e.g Zimbabwe lack recommended manure management practices, such as roofing animal housing, having a water-proof floor or covering manure during storage, causing large nutrient losses during manure storage, increasing greenhouse gas emissions, and reducing the quality of the manure as a fertilizer (AGRA, 2013).

Close to $70 \%$ of the communal farmers in Zimbabwe rely on the integrated crop-livestock production system for their livelihoods (Matarauka and Samaz, 2014). Livestock benefits from crop residues during drier months when grazing is scarce and the nutritive value of grass is low ( Mariaselvam et al., 2015). The manure from cattle is used in crop fields with or without inorganic fertilisers (Larney et al., 2006). Cattle manure is commonly used for enhancing soil fertility in the farming sector of Zimbabwe; however, its fertilizer value is frequently reduced due to poor handling and management (Wuta and Nyamugafata, 2012). Oftentimes, the smallholder farmers do not have access to technological inputs, which makes them heavily dependent on land resources for their outputs. However, the poor soil fertility has been widely accepted as a major factor limiting the agricultural productivity of smallholder farms in Africa as a whole (AGRA, 2013).

The manure is usually collected from animal houses e.g cattle kraals, fowl runs and pig stays. After collection, the manure can be stored or composted before use, and nutrient losses may occur through leaching and volatilization (Rufino et al., 2006). Regardless of the encountered losses of nutrients during storage, manure is still considered a valuable output of livestock. The principal factors that influence nutrient composition of manure are type of livestock, growth stage and feeding practices as well as the amount and type of bedding or water added to the manure, type of manure storage, time that the manure is stored and weather conditions (Jakhro et al., 2017). The type and quantity of bedding materials determines if the manure will be managed as solid, semi-solid or liquid (Mariaselvam et al., 2015). Bedding can include wood chips, rice or peanut hull, sawdust, flax straw, wheat straw and recycled paper products. Improvement of manure quality can be enhanced through effective handling management practices, resulting to increased soil productivity (Matarauka and Samaz, 2014).

The effectiveness of animal manure as a fertilizer depends critically on its handling and storage methods, and on synchronizing mineralization of manure $\mathrm{N}$ with crop uptake (Rufino et al., 2006). A well-managed manure, increases soil and crop productivity, but associated with other co-benefits, like reducing nitrate $\left(\mathrm{NO}_{3}^{-}\right)$and phosphorus (P) leaching, as well as reducing both ammonia $\left(\mathrm{NH}_{3}\right)$ volatilization and nitrous oxide $\left(\mathrm{N}_{2} \mathrm{O}\right)$ and methane $\left(\mathrm{CH}_{4}\right)$ emissions (Efthimiadou et al., 2012). However, poor manure management can lead to the outbreak of zoonotic diseases in humans (Mariaselvam et al., 2015). Farmers can adopt practices that efficiently integrate use of manure in crop production in order to optimize the benefits from the manure. Nevertheless, the manure management practices in the resource poor communal farmers is still unknown in Zimbabwe. The objectives of this study was to describe the common manure management practices in the communal farming system, determine the factors that affect use of manure as a fertilizer and establish the effects of various manure management practices on vegetable yield.

\section{Methodology}

\subsection{Site Description}

The survey was carried out in wards $7\left(18^{\circ} 01^{\prime} 98^{\prime \prime} \mathrm{S}\right.$ and $31^{\circ} 06^{\prime} 79^{\prime \prime}$ E) in Seke communal area, Zimbabwe. 
The Seke area is situated about $36 \mathrm{~km}$ south of Harare the capital city of Zimbabwe. The study area is in agro-ecological region IIb. It is characterised by hot wet summers (rainy season) (October to April) and cold dry winters (May to July). The area receives an average annual rainfall of $850 \mathrm{~mm}$ and an average maximum and minimum temperatures are $25.3 \mathrm{C}^{\circ}$ and $12.2^{\circ} \mathrm{C}$ respectively. The Seke is known to have high inter-annual rainfall variability with a coefficient of variation of between $23-40 \%$. The predominant soil type is sandy textured soils derived from granitic parent material, classified as Lixisol (FAO soil classification)

\subsection{Research Methodology}

(1) Sampling procedure and data collection

A manure management practices survey using an exploratory soil survey in April-August 2019. A total of 222 horticultural farmers were sampled from the Seke district, Zimbabwe. The data was collected at the farm level, with the unit of study being the household. The focus was on one ward with a total population of 1250 households and three villages selected at random. The villages experience a similar rainfall and cropping pattern. A multistage sampling procedure was used, involving random sampling of three villages, stratified according to farming activities and wealth status and a resultant random selection of participating households. Key informant interviews were carried out on agricultural extension officers from the area. A questionnaire was used to interview a total of 222 households randomly selected from the selected three villages. At least 74 households from each of the villages were interviewed by trained enumerators using Shona, the local vernacular language.

(2) Manure sampling and analysis

A sub-sample of 15 farmers was randomly obtained from the 222 farmers used in the survey. Then a $500 \mathrm{~g}$ of manure (i.e drying, composting and anaerobic digestion) was randomly sampled from the bulk treated manure. A total of 45 samples were taken for analysis. The manure $\mathrm{pH}$ and ECs were measured in a soil water suspension (ratio of 1:5) using a TPS meter as described by Okalebo et al. (2000). The $C \& N$ in the manure were determined using a method described by Parwada and Van Tol (2018). The Olsen extractable $\mathrm{P}$, exchangeable ammonium and nitrate and nitrite were determined as was described by Parwada et al. (2018).

(3) Data analysis

Data collected from the field was analysed with the Statistical Package for Social Sciences (SPSS) version 23 and Microsoft Excel. Both descriptive and inferential statistics were used. Descriptive statistics were mainly frequency tables and percentage indices, while inferential statistics the Spearman rank correlation. The Chi-square tests of independence were used to test for associations of manure management with the demographic variables. The Spearman rank correlation was done to measure the noncause-effect relationship between different independent variables and farmers' management practice of manure.

\section{Results and Discussions}

\subsection{Demographic Information}

The Seke communal area is characterised by more females $(52 \%)$ than males $(48 \%)$ who are involved in farming (Table 1). Most (45\%) of the respondents were $31-40$ years old, $46 \%$ used poultry manure as a source of fertilizer and $48 \%$ had primary and secondary (level 1) education. The majority ( $88 \%$ ) own $<1$ ha of land and horticulture farming $(78 \%)$ is the main land use in the study area (Table 1).

Table 1. Respondent profiles

\begin{tabular}{|c|c|}
\hline & $\%$ of respondents \\
\hline \multicolumn{2}{|l|}{ Gender } \\
\hline Women & 52 \\
\hline Men & 48 \\
\hline \multicolumn{2}{|l|}{ Age (years old) } \\
\hline $18-30$ & 9 \\
\hline $31-40$ & 45 \\
\hline $41-60$ & 32 \\
\hline$>61$ & 14 \\
\hline \multicolumn{2}{|l|}{ Common sources of manure } \\
\hline Cattle & 18 \\
\hline Goat and/sheep & 33 \\
\hline Chicken & 46 \\
\hline Others & 3 \\
\hline \multicolumn{2}{|l|}{ Land size (ha) } \\
\hline$<1$ & 88 \\
\hline $1-2.9$ & 11 \\
\hline$>3$ & 1 \\
\hline \multicolumn{2}{|l|}{ Education* } \\
\hline Level 0 & 14 \\
\hline Level 1 & 48 \\
\hline Level 2 & 38 \\
\hline \multicolumn{2}{|l|}{ Main sources of income } \\
\hline Farming (horticulture) & 78 \\
\hline Employment other farming & 14 \\
\hline Other sources & 8 \\
\hline
\end{tabular}

*Level $0=$ no formal education, Level $1=$ Primary \& Education School, Level $2=$ tertiary 
The observed demographic structure in the Seke communal area could be due to high rural-urban migration by the males. Women are usually left behind in the rural areas while their husbands migrate to urban areas seeking employment opportunities. A similar rural demographic structure due to the rural-urban migration was observed by FAO (2006) who noted a majority of smallholder farmers in rural Zimbabwe to be women. Additionally, at least $86 \%$ of the Zimbabwean women are dependent on the land for income (FAO 2006). These findings are consistent with AREX (2004) who concur that a greater number of women constitute unpaid family farm workforce where they work for 16-18 hours a day. At least $49 \%$ of their time is devoted to farming activities and about $25 \%$ on domestic activities (ZimStat, 2014). Unfortunately, out of the vast arable land area in Zimbabwe, very little of it is owned by women (Mudavanhu et al., 2012). This skewed land ownership toward the men could be the reason for the high frequency response on respondents with $<1$ ha of land (Table 1). Regardless of the fact that the women constitute a larger population than men in Zimbabwe (ZimStat, 2014), majority of rural women lack property ownership, and women's access to land is only through their husbands, fathers, brothers or sons (Mudavanhu et al., 2012).

\subsection{Types of Livestock and Manure Quantity}

Chicken and pigs are the most ( $>50 \%)$ and less common $(1 \%)$ owned type of livestock respectively. A few farmers $(<8 \%)$ indicated they own cattle in the Seke communal area (Figure 1).

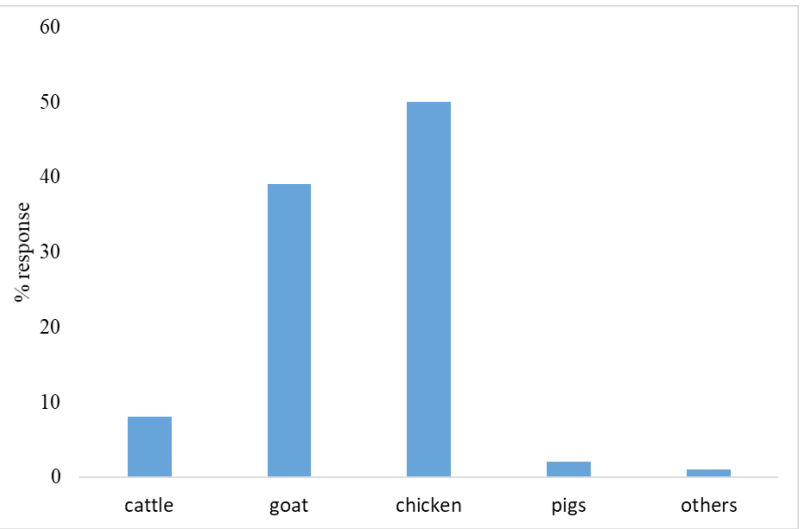

Figure 1. Percentage response on the common type of animals owned in the Seke communal area, Zimbabwe

The chicken manure was most (51\%) frequently used as a fertilizer but with the least $(<0.5 \mathrm{t} / \mathrm{ha})$ application quantities whereas the cattle manure was commonly applied in largest ( $>0.5 \mathrm{t}$ ha) quantities (Figure 2).



Figure 2. Percentage use of manure $\left(\mathrm{t} \mathrm{ha}^{-1} \mathrm{yr}^{-1}\right)$ per animal at the Seke communal area, Zimbabwe

Usually the chicken manure is produced in smaller quantities than the cattle manure. The farmers would frequently apply the chicken manure on small vegetable beds (usually $2 \mathrm{~m}^{2}$ each in size) in their home gardens at least 2 twice a year depending on the type of vegetable. However, the farmers rely on the cattle manure for their fields because they would want to apply on a large $\left(>2 \mathrm{~m}^{2}\right)$ area. The chicken could not produce enough manure to cover their fields but the cattle kraals would produce a significantly high quantity of manure.

\subsection{Knowledge of Manure Management Practices}

Many farmers $(>50 \%)$ indicated that they were void of information on animal manure management (Table $2)$. There were significant $(\mathrm{P}<0.05)$ associations between the availability of manure management information and demographics (gender, age and education). Women who were $>61$ years old and $>$ level 1 of education showed to have information on the manure management, whereas the less educated (<level 1) men lacked the knowledge on manure management (Table 2). The lack of information on manure management was cited as the most $(90 \%$ of respondent) crucial constraint to enhanced manure management (Table 2). The farmers showed to have insufficient knowledge on the manure management practices and their potential benefits especially at the household level. The problem is usually aggravated by the exclusion of manure management in most agricultural extension training schemes (Matarauka and Samaz, 2014).

At least $90 \%$ of respondents affirmed that they apply cattle manure yearly and $84 \%$ applied goat manure biannually. Old age (31+ years old) with high education (level $1+$ ) mostly applied the animal manure biannual (Table 2). Eighty five percent and $9 \%$ of the respondents showed that the animal manure was readily available and unavail- 
able respectively. Only $6 \%$ of the respondents indicated that they do not own any of the animal types hence manure was unavailable (Table 2). Gender, age, common sources of manure and education significantly $(\mathrm{P}<0.05)$ influenced the manure availability and management practices in the Seke area (Table 2). All (100\%) respondents claimed positive and significant $(\mathrm{P}<0.05)$ associations between the common manure management practices (drying, composting and anaerobic digestion) and crop yield benefits, gender, age and level of education $(\mathrm{P}<0.05)$ (Table 2).

The manure from various animals is readily available in the Seke communal area however, poorly managed. Animal housing is poorly constructed, commonly fencing only (Figure 3) so the manure is exposed to adverse weather conditions leading to rapid reduction in quality. Farmers indicated lack of information on the proper management of the manure. This suggests that much of the manure may be lost both in the quantity and quality if the community is not educated on the handling and storage of the manure.

\subsection{Livestock Housing and Manure Collection}

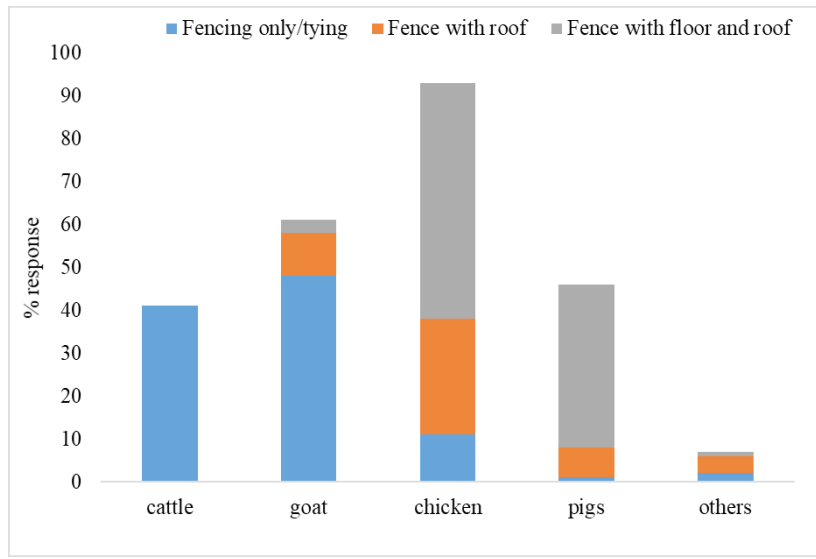

Figure 3. Animal confinement used in the manure collection and management in the Seke area, Zimbabwe.

Forty one percent and $48 \%$ of the respondents indicated

Table 2. The percentage of the respondent on the knowledge of manure management in Seke, ward 7, Zimbabwe ( $\mathrm{n}=222)$.

\begin{tabular}{|c|c|c|c|c|c|c|c|c|c|c|c|c|c|c|}
\hline \multirow{2}{*}{$\%$ Respondents } & \multirow{2}{*}{ All } & \multicolumn{2}{|c|}{ Gender } & \multicolumn{3}{|c|}{ Age (years old) } & \multicolumn{5}{|c|}{ Common sources of manure } & \multicolumn{3}{|c|}{ Education** } \\
\hline & & Women & Men & $18-30$ & $31-40$ & $41-60$ & $>61$ & Cattle & Goat & Chicken & Others & Level 0 & Level 1 & Level 2 \\
\hline \multicolumn{15}{|c|}{ Availability of information on manure use and management } \\
\hline Yes & 10 & 20 & 4 & $3 *$ & $5^{*}$ & $28^{*}$ & $26^{*}$ & - & - & - & - & $1^{*}$ & $8^{*}$ & $11 *$ \\
\hline No & 90 & 35 & 16 & $38^{*}$ & $19^{*}$ & 9* & $4 *$ & - & - & - & - & $3 *$ & $5^{*}$ & $3 *$ \\
\hline \multicolumn{15}{|l|}{ Frequency of manure application } \\
\hline Never & 88 & 12 & 26 & $12 *$ & $14^{*}$ & $5^{*}$ & 0 & $2 *$ & $10^{*}$ & $0^{*}$ & $0^{*}$ & $8^{*}$ & $0^{*}$ & $0^{*}$ \\
\hline Yearly & 10 & 8 & 65 & $9^{*}$ & $50^{*}$ & $4^{*}$ & $12 *$ & $90 *$ & $6^{*}$ & $88^{*}$ & $75^{*}$ & $63^{*}$ & $13^{*}$ & $2^{*}$ \\
\hline Biannually & 2 & 78 & 9 & $79 *$ & $60^{*}$ & $91^{*}$ & $88^{*}$ & $8^{*}$ & $84 *$ & $12 *$ & $25^{*}$ & $29^{*}$ & $87^{*}$ & $98 *$ \\
\hline \multicolumn{15}{|c|}{ Yield benefits of using manure } \\
\hline Yes & 100 & $80^{*}$ & $99 *$ & $95^{*}$ & $99^{*}$ & $98^{*}$ & $97^{*}$ & $99 *$ & $98^{*}$ & $94 *$ & $100 *$ & $100 *$ & $97^{*}$ & $99 *$ \\
\hline No & 0 & $20^{*}$ & $1 *$ & $5^{*}$ & $1^{*}$ & $2 *$ & $3 *$ & $1^{*}$ & $2^{*}$ & $6^{*}$ & $0^{*}$ & $0^{*}$ & $3^{*}$ & $1^{*}$ \\
\hline \multicolumn{15}{|c|}{ Availability of manure } \\
\hline Readily available & 85 & $79^{*}$ & $88^{*}$ & $93^{*}$ & $94^{*}$ & $95^{*}$ & $99 *$ & $92 *$ & $97^{*}$ & $99 *$ & $100^{*}$ & $93^{*}$ & $93^{*}$ & $1^{*}$ \\
\hline Unavailable & 9 & $1 *$ & $2^{*}$ & $2^{*}$ & $4 *$ & $4^{*}$ & $1 *$ & $2^{*}$ & $2^{*}$ & $0^{*}$ & $0^{*}$ & $4^{*}$ & $7 *$ & $99 *$ \\
\hline Do not own animals & 6 & $20^{*}$ & $10^{*}$ & $5^{*}$ & $2 *$ & $1^{*}$ & $0^{*}$ & $6^{*}$ & $1^{*}$ & $1 *$ & $3^{*}$ & $3^{*}$ & $0^{*}$ & $0^{*}$ \\
\hline \multicolumn{15}{|c|}{ Common manure treatment practices } \\
\hline Drying (July-September) & 82 & $70^{*}$ & $88^{*}$ & $77^{*}$ & $91^{*}$ & $80^{*}$ & $8^{*}$ & $76^{*}$ & $82 *$ & $75^{*}$ & $86^{*}$ & $50^{*}$ & $9^{*}$ & $10^{*}$ \\
\hline Compositing & 5 & $10^{*}$ & $1^{*}$ & $2^{*}$ & $0^{*}$ & $6^{*}$ & $1^{*}$ & $12 *$ & $8^{*}$ & $10^{*}$ & $5^{*}$ & $50^{*}$ & $26^{*}$ & $0^{*}$ \\
\hline Anaerobic digestion & 13 & $20^{*}$ & $11^{*}$ & $21^{*}$ & $9^{*}$ & $14^{*}$ & $91^{*}$ & $12^{*}$ & $10^{*}$ & $15^{*}$ & $9^{*}$ & $15^{*}$ & $65^{*}$ & $80^{*}$ \\
\hline
\end{tabular}

$* \mathrm{P}<0.05$ : for each Chi-square test, the percentage shown represent column proportions. ${ }^{* *}$ Level $0=$ no formal education, Level $1=$ Primary $\&$ Education School, Level $2=$ tertiary (a holder of at least a certificate up to a $\mathrm{PhD}$ ) 
that they confined cattle and goats by fencing only/tying respectively. The chickens were confined mostly $(55 \%)$ by fencing with floor and roof (Figure 3).

Animal housing affects the quantity and quality of manure. In the communal areas of Zimbabwe, cattle are usually herded in grazing areas during the day and penned at night in kraals located nearer the homestead (Nzuma and Murwira, 2000). This results in more manure being collected during the night than day. If penned all day, one livestock unit ( $1 \mathrm{LU}=500 \mathrm{~kg}$ live mass $)$ can produce about $1.5 \mathrm{t}$ of recoverable manure per year (Mugwira and Murwira, 1997). The manure that accumulates in the kraals is then dug out towards the end of winter season (July) and heaped to cure for at least three months before use. However, the amount of usable manure that cattle can provide depends on several factors such as the amount of feed, the feeding method (pen rearing, kraaling the animals at night or free range) and the manure collection efficiency. Manure produced at the grazing sites is difficult to collect and usually is not used for crop production at all. Scavenging animals, in particular the chickens (road runners), deposited most of their manure around the household, which was not usually collected.

The heaping of manure is done to improve the quality of the manure as a fertilizer as it argued that organic manures are usually late in nutrient mineralization. Hence, the need to cure the manures in order to reduce the time of mineralization on the field (Jakhro et al., 2017). The nature of the animal house can regulate the temperature around the manure and affects its quality. The temperature strongly influences all microbiological processes where higher temperatures lead to higher rates of nitrification, denitrification and decomposition of organic manure $(\mathrm{Ru}-$ fino et al., 2006). Fencing with roofing and floor can moderate the temperature and reduce the rate of quality loss in the manure. Considering that more than $48 \%$ of the farmers did not put floor nor roof the cattle and goats houses, nitrates will be formed faster and leached the manure. In a fenced only house, the manure will be in direct contact with the soil hence increasing the rate of nutrient leaching from the manure. During the rainy season, fencing the animal house only will promote leaching of $\mathrm{NO}_{3}, \mathrm{P}$, other nutrients and organo-chlorines (Hao and Chang, 2013).

The poultry manure was commonly collected as a mixture of bedding material, feed waste, flushing water, feathers, soil together with the chicken excreta that will obviously affect the nutrient content. The bedding put in the chicken houses can conserve nutrients in the manure if it partly covers the manure and can prevent ammonia volatilization (Mariaselvam et al., 2015). However, the bedding can increase the $\mathrm{C}: \mathrm{N}$ of the manure (Table 4) because the bedding materials (e.g., straw) usually have lower $\mathrm{N}$ concentration than the animal excreta resulting to increased organic carbon content in the manure (Rufino et al., 2006). The increasing C:N ratio will enhance $\mathrm{N}$ immobilization by soil microbes reducing volatilization losses (Efthimiadou et al., 2012). However, proper timing of application is very critical as the $\mathrm{N}$ immobilization by microbes may reduce $\mathrm{N}$ availability for the growing crop.

\subsection{Manure Management Practice and Applica- tion Approach}

The common type of manure categories in the Seke communal area were the solid/drylot (90\%), mixed (60\%) and liquid $(40 \%)$ manure. The manure categories were dependent on the animal type where the drylot was common with chicken, cattle and goat manure but pig manure was mostly managed as liquid (Figure 4).



Figure 4. The common animal manure categories used for vegetable production in the Seke communal area, Zimbabwe.

There are many different manure storage systems (Chang and Entz, 2016), however in the Seke district, the farmers used solid storages with no collection or storage of urine. In the drylot systems where animals graze freely during the day and spend the nights inside the kraal, the manure is managed as a drylot system, the animals deposit much of the manure in the kraal which is allowed to pile up before infrequent collection. (Table 2). In other systems where animals are confined (such as in zero grazing), dung is collected and stored in heaps, mostly without a hard floor or cover.

$90 \%$ of the respondents indicated that they use the drylot management practice mainly with the chicken, goat and cattle manure (Figure 4). In this management practice, the urine was not collected and bedding was sparsely used. This could result in high losses of $\mathrm{N}$ and $\mathrm{K}$ in partic- 
ular as most of the urine is lost. Coupled with the animal housing and manure storage facilities together with time, part of the nutrients in the manure can be leached and lost through surface runoff during rain and uncovered manure. The collection of the urine in the case of floored and roofed animal houses will reduce $\mathrm{K}$ losses. Using bedding, with sufficient absorption capacity to capture urine, might reduce $\mathrm{N}$ losses (Hao and Chang, 2013).

Less than $30 \%$ of the respondents indicated that they used a liquid system (mainly from pigs). In this manure management practice, the faeces and urine are stored together. In the liquid system, the volatilization losses will be dependent on the level of ventilation, depth of storage tanks and storage time, but often range between 5 and $35 \%$ of the total $\mathrm{N}$ excreted (Matarauka and Samaz, 2014). In the liquid manure, approximately $50 \%$ of the $\mathrm{N}$ is $\mathrm{NH}_{3}-\mathrm{N}$ in solution and the $\mathrm{NH}_{3}$ has high vapour pressure so it will readily volatilize upon exposing the manure to the air (Chang and Entz, 2016). The greater the exposure, i.e. a larger specific area in contact with the air, the more $\mathrm{NH}_{3}$ volatilization. Quality loss will be high if the manure is stored directly in contact with the soil (fence only house) and the liquid can seep into the soil leaching the N, P, K, organic and other compounds.

\subsection{Effects of Animal Manure Treatment and Ap- plication Method on Vegetable Production}

The farmers indicated to apply the manure in holes, furrows or broadcast on different types of vegetables (Table 3). The manure application method was significantly $(\mathrm{P}<0.05)$ influenced by the manure treatment method and the crop type.

The hole application method was significantly $(\mathrm{P}<0.05)$ influenced by drying the manure on all the vegetables grown in the Seke communal area (Table 3). Anaerobic digestion did not significantly $(\mathrm{P}>0.05)$ influence the manure application method in all the grown vegetables. The farmers in the Seke communal area preferred drying with hole application of manure to anaerobic digestion (Table 3). The method of manure application is very important as it determines the effectiveness of the manure as a fertilizer. Manure should be incorporated into the soil immediately after application, in order to retain more nutrients for plant growth (Mugwira and Murwira, 1997). Larney et al. (2006) noted that about $90 \%$ of $\mathrm{N}$ from liquid manure will be available for plant growth if incorporated within $8 \mathrm{~h}$ compared to only $40 \% \mathrm{~N}$ availability if incorporated 5-7 days application. It is worth noting that in the Seke

Table 3. Spearman rank correlation coefficient $\left(\mathrm{r}_{\mathrm{s}}\right)$ on effects of manure treatment and application methods on yield of selected common crops in Seke district, Zimbabwe

\begin{tabular}{|c|c|c|c|c|}
\hline \multirow[b]{2}{*}{ Crop } & \multirow[b]{2}{*}{ Application method } & \multicolumn{3}{|c|}{ Manure treatment methods } \\
\hline & & Drying & Composting & Anaerobic digestion \\
\hline & Hole & $0.69^{*}$ & $0.53 *$ & 0.34 \\
\hline \multirow[t]{3}{*}{ Leaf vegetables } & Furrow & $0.71 * *$ & 0.42 & 0.28 \\
\hline & Broadcast & 0.33 & 0.38 & 0.17 \\
\hline & Hole & $0.63^{*}$ & $0.61 *$ & 0.50 \\
\hline \multirow[t]{3}{*}{ Tomatoes } & Furrow & $0.55^{*}$ & $0.70 * *$ & 0.30 \\
\hline & Broadcast & 0.43 & 0.37 & 0.21 \\
\hline & Hole & $0.73 * *$ & $0.70^{*}$ & 0.32 \\
\hline \multirow[t]{3}{*}{ Potatoes } & Furrow & $0.59^{*}$ & 0.45 & 0.22 \\
\hline & Broadcast & 0.36 & 0.30 & 0.16 \\
\hline & Hole & $0.50^{*}$ & 0.39 & 0.30 \\
\hline \multirow[t]{3}{*}{ Cucumber } & Furrow & 0.48 & 0.24 & 0.25 \\
\hline & Broadcast & 0.28 & 0.19 & 0.14 \\
\hline & Hole & $0.57 *$ & $0.65^{*}$ & 0.44 \\
\hline \multirow[t]{2}{*}{ Onion } & Furrow & 0.43 & 0.44 & 0.29 \\
\hline & Broadcast & 0.34 & 0.26 & 0.17 \\
\hline
\end{tabular}

* and ** means significant at $\mathrm{P}=0.05$ and 0.001 respectively 
communal area, the urine and liquid manure are not often managed or applied to agricultural soils, but are left to (over) flow, so they either end up in the soil or washed into water bodies without any treatment.

The manure treatment methods had varied effects on the manure quality where the drying preserved more nutrients from loss compared to the composting and anaerobic digestion (Table 4). However, the nutrient content of the manure per animal type varied significantly depending on the used manure treatment method. Generally, the chicken manure had the lowest $\mathrm{C} / \mathrm{N}$ ratios across all the three treatment methods compared to the cattle and goat manure.

The nutrient composition of manure at the time of application and its ability to provide nutrients for crop growth is influenced by the initial nutrient status of manure and on its management (Larney et al., 2006). The initial nutrient content of manure depends primarily on the animal type or breed, feeding practice and feed quality. Table 4 shows the composition of different manures, where poultry manure contains the highest nutrient concentrations. General, monogastrics (poultry and pigs) produced manure of higher nutrient content as compared to ruminants (cattle and goat) (Table 4) though, by quantity most of the manure available on farms was from cattle and goats (Figure 2). The manure management practices can alter the manure quality by modifying the effects of environmental conditions such as temperature, rainfall and humidity that usually influence the rate of nutrient loss from the manure (Nzuma and Murwira, 2000). The choice of manure treatment coupled with the housing type can modify the quality of the manure. Usually the fencing only is associated with higher rates of quality loss than the fencing and flooring and the fencing with floor and roof (Figure 3). Drying and composting did maintain the

Table 4. Effects of different manure treatment practices on its nutritional quality in the Seke communal area, Zimbabwe.

\begin{tabular}{|c|c|c|c|c|}
\hline Manure source & Parameter & Drying & Composting & Anaerobic digestion \\
\hline \multirow{7}{*}{ Cattle } & $\mathrm{pH}(\mathrm{H} 2 \mathrm{O})$ & $7.9 \pm 0.2$ & $7.6 \pm 0.2$ & $7.2 \pm 0.2$ \\
\hline & $\mathrm{EC}(\mathrm{cmol}(+) \mathrm{kg}-1)$ & $590.3 \pm 20.3$ & $400.2 \pm 20.3$ & $234.0 \pm 20.3$ \\
\hline & Total C (\%) & $28.9 \pm 5.1$ & $19.0 \pm 5.1$ & $7.1 \pm 5.1$ \\
\hline & Total N (\%) & $1.1 \pm 0.1$ & $0.8 \pm 0.1$ & $0.2 \pm 0.1$ \\
\hline & $\mathrm{C}: \mathrm{N}$ ratio & $26.3 \pm 0.5$ & $23.8 \pm 0.5$ & $35.5 \pm 0.5$ \\
\hline & Olsen extractable P (mg kg-1) & $910.0 \pm 11.2$ & $804.4 \pm 11.2$ & $304.4 \pm 11.2$ \\
\hline & Extractable NH4 (mg kg-1) & $278.2 \pm 8.4$ & $261.6 \pm 8.4$ & $123.6 \pm 8.4$ \\
\hline \multirow{7}{*}{ Goat } & $\mathrm{pH}(\mathrm{H} 2 \mathrm{O})$ & $7.5 \pm 0.2$ & $7.2 \pm 0.2$ & $7.8 \pm 0.2$ \\
\hline & $\mathrm{EC}(\mathrm{cmol}(+) \mathrm{kg}-1)$ & $617.3 \pm 20.3$ & $502.5 \pm 20.3$ & $278.1 \pm 20.3$ \\
\hline & Total C (\%) & $21.4 \pm 5.1$ & $19.9 \pm 5.1$ & $10.4 \pm 5.1$ \\
\hline & Total N (\%) & $2.1 \pm 0.4$ & $1.1 \pm 0.4$ & $0.4 \pm 0.4$ \\
\hline & $\mathrm{C}: \mathrm{N}$ ratio & $10.2 \pm 0.5$ & $18.1 \pm 0.5$ & $26.0 \pm 0.5$ \\
\hline & Olsen extractable P (mg kg-1) & $1200.0 \pm 11.2$ & $1198.1 \pm 11.2$ & $682.7 \pm 11.2$ \\
\hline & Extractable NH4 (mg kg-1) & $258.3 \pm 8.4$ & $243.6 \pm 8.4$ & $118.2 \pm 8.4$ \\
\hline \multirow{7}{*}{ Chicken } & $\mathrm{pH}(\mathrm{H} 2 \mathrm{O})$ & $7.1 \pm 0.2$ & $7.8 \pm 0.2$ & $7.9 \pm 0.2$ \\
\hline & $\mathrm{EC}(\mathrm{cmol}(+) \mathrm{kg}-1)$ & $634.4 \pm 20.3$ & $569.1 \pm 20.3$ & $323.8 \pm 20.3$ \\
\hline & Total C (\%) & $13.6 \pm 5.1$ & $12.7 \pm 5.1$ & $10.7 \pm 5.1$ \\
\hline & Total N (\%) & $8.15 \pm 0.8$ & $7.06 \pm 0.8$ & $2.1 \pm 0.8$ \\
\hline & $\mathrm{C}: \mathrm{N}$ ratio & $1.7 \pm 0.5$ & $1.8 \pm 0.5$ & $5.1 \pm 0.5$ \\
\hline & Olsen extractable P (mg kg-1) & $1524.0 \pm 11.2$ & $1456.7 \pm 11.2$ & $867.6 \pm 11.2$ \\
\hline & Extractable NH4 (mg kg-1) & $321.3 \pm 8.4$ & $241.6 \pm 8.4$ & $165.0 \pm 8.4$ \\
\hline \multirow{7}{*}{ Pigs } & $\mathrm{pH}(\mathrm{H} 2 \mathrm{O})$ & $7.8 \pm 0.2$ & $7.7 \pm 0.2$ & $7.9 \pm 0.2$ \\
\hline & $\mathrm{EC}(\mathrm{cmol}(+) \mathrm{kg}-1)$ & $516.5 \pm 20.3$ & $410.3 \pm 20.3$ & $299.1 \pm 20.3$ \\
\hline & Total C (\%) & $13.9 \pm 5.1$ & $11.8 \pm 5.1$ & $8.2 \pm 5.1$ \\
\hline & Total N (\%) & $6.13 \pm 0.3$ & $3.9 \pm 0.3$ & $0.9 \pm 0.3$ \\
\hline & $\mathrm{C}: \mathrm{N}$ ratio & $2.3 \pm 0.5$ & $3.0 \pm 0.5$ & $9.1 \pm 0.5$ \\
\hline & Olsen extractable P (mg kg-1) & $1034.0 \pm 11.2$ & $998.5 \pm 11.2$ & $578.7 \pm 11.2$ \\
\hline & Extractable NH4 (mg kg-1) & $289.5 \pm 8.4$ & $273.8 \pm 8.4$ & $152.1 \pm 8.4$ \\
\hline
\end{tabular}


nutrient content of the manure but the anaerobic digestion resulted in high loss of nutrients from the manure (Table 4). In the anaerobic digestion, much of the carbon and nitrogen are converted into gas and little nutrients will be left (Table 4) for crop growth therefore most farmers do not benefit much from this type of manure hence rarely used (Table 3).

\section{Conclusion and Recommendations}

The major type of animal housing (fence only) in the study is prone to high losses in manure quality. Manure collection was ineffective because a large part of the manure is uncollected, especially faeces produced by scavenging animals like cattle and chicken. The manure was commonly treated by drying, composting and anaerobic digestion and drying preserved more nutrients from loss compared to the other treatment methods. The farmers preferred drying and hole application of the manure on vegetables production to other practices. However, gender, age, education and a lack of information limited the use and management of the animal manure. A large number of farmers stored the manure on unroofed and permeable floors resulting in high nutrient losses from the manure by rain and sun. Well managed animal manure can unlock numerous benefits like the modification of soil properties e.g increased soil water holding capacity thereby increasing crop productivity under low rainfall. There is need to avail information on manure management among the farmers through extension services aiming at capacity building like vocational training, exposure visits between farmers as well as a lead farm approach of extension. At the household level, farmers should fence, floor and roof the animal houses aiming at improving the quantity and quality of the animal manure. Further research on the use of manure and demonstrate the suitability and benefits well managed manure are required.

\section{Acknowledgements}

The research did not receive any specific funding, but was performed as part of employment at the Marondera University of Agricultural Sciences and Technology and the Women's University in Africa, Zimbabwe. The authors gratefully acknowledge the communal farmers in the ward 7, Seke district, Zimbabwe for allowing us to carry this study in their area.

\section{Competing Interests}

The authors declare that they have no competing interests

\section{Data Availability Statement}

The raw data used to support the findings of this study are available from the corresponding author upon request.

\section{References}

[1] AGRA. 2013. Africa Agriculture Status Report: Focus on Staple Crops. Nairobi: Alliance for Green Revolution in Africa (AGRA). Available online at: http:// agra-alliance.org/download/533977a50dbc7/

[2] AREX. 2004. Zimbabwe. Dept. of Agricultural Research \& Extension "National Report." Volume 3, Harare.

[3] Bindraban, P., Mose, L., Hillen, M., Gonzalez, M. R., Voogt, M., Leenaars, J., Langeveld, K. and Heerink, N. 2018. Smart fertilization and water management - Kenya - Netherlands Aid-and-Trade opportunities. IFDC Report 2018/1. International Fertilizer Research Center, Muscle Shoals, Alabama, USA pp. 102 .

[4] Chang, C and Entz, T. 2016. Nitrate leaching losses under repeated cattle feedlot manure applications in southern Alberta. J. Environ. Qual. 25: 145-153

[5] Efthimiadou, A., Froud-Williams, R.J., Eleftherohorinos, I., Karkanis, A, and Bilalis, D.J. 2012. Effects of organic and inorganic amendments on weed management in sweet maize. International Journal of Plant Production 6, 291-307

[6] FAO. 2006. World reference base for soil resources 2006: A framework for international classification, correlation, and communication. World Soil Resources Reports, 103: 145.

[7] Hao, X and Chang, C. 2013. Does Long-Term Heavy Cattle Manure Application Increase Salinity of a Clay Loam Soil in Semi-Arid Southern Alberta. Agriculture Ecosystems and Environment, 94: 89-103.

[8] Jakhro, M. I., Shah, S.I., Amanullah, A., Zehri, M.Y., Rahujo, Z.A., Ahmed, S and Jakhro, M.A. 2017. Growth and yield of spinach (Spinacia oleracia) under fluctuating levels of organic and inorganic fertilizers. International journal of development research. 7: 11454-11460.

[9] Larney, F.J., Sullivan, D.M., Buckley, K.E and Eghball, B. 2006. The role of composting in recycling manure nutrients. Can. J. Soil Sci. 86: 597-611.

[10] Mariaselvam, A.A, Dandeniya, W.S., Indraratne, S.P and Dharmakeerthi, R.S. 2015. "High C/N Materials Mixed with Cattle Manure as Organic Amendments to Improve Soil Productivity and Nutrient Availability." Tropical Agricultural Research 25 (2): 201. https://doi.org/10.4038/tar.v25i2.8142

[11] Matarauka, D and Samaz, M. 2014. "Organization of 
Manure from Ruminant (Cattle and Goat) in Wedza Smallholder Farming Area, Zimbabwe." International Journal of Manures and Fertilizers. Vol. 3. www. internationalscholarsjournals.org

[12] Mudavanhu, V., Muchabaiwa, L., Chigusiwa, L., Bindu, S., Mapfumo, T., Karambakuwa, R and Chingarande, A. 2012. The role of women in reducing absolute poverty in rural Zimbabwe: A Case Study of Bindura District (2008 to 2011). International Journal of Management Sciences and Business Research 1 (10): ISSN (2226-8235)

[13] Mugwira, L.M and Murwira, H.K. 1997. "Use of Cattle Manure to Improve Soil Fertility in Zimbabwe : Past and Current Research and Future ZIMBABWE : PAST AND CURRENT RESEARCH AND FUTURE," no. 2: 1-33

[14] Nzuma, J.K and Murwira, H.K. 2000. Improving the management of manure in Zimbabwe. Managing Africa's soil. Russel Press, Nottingham. 15: 20.

[15] Okalebo, J.B., Gathua, K.W and Woomer, P.L. 2000. Laboratory Methods of Soil and Plant Analysis: A Working Manual. TSBF-KARI-UNESCO, Nairobi,

\section{Kenya}

[16] Parwada, C and Van Tol, J. 2018. Effects of litter source on the dynamics of particulate organic matter fractions and rates of macroaggregate turnover in different soil horizons. European Journal of Soil Science. doi: 10.1111/ejss.12726

[17] Rufino, M. C., Rowe, E. C., Delve, R. J and Giller, K. E. 2006. Nitrogen cycling efficiencies through resource-poor African crop-livestock systems. Agric. Ecosys. Environ. 112, 261-282. doi: 10.1016/ j.agee.2005. 08.028

[18] Rusinamhodzi, L., Corbeels, M., Zingore, S., Nyamangara, J and Giller, K.E., 2013. Pushing the envelope? Maize production intensification and the role of cattle manure in the recovery of degraded soils in smallholder farming areas of Zimbabwe. Field Crops

[19] Wuta, M and Nyamugafata, P. 2012. Management of cattle and goat manure in Wedza smallholder farming area, Zimbabwe. African Journal of Agricultural Research. 7: 3853-3859.

[20] ZIMSTAT. 2014. Compendium of statistics 2014. Harare, Zimbabwe. 